\title{
Normal sensory conduction in the nerves of the leg in man
}

\author{
FRIEDRICH BEHSE AND FRITZ BUCHTHAL \\ From the Institute of Neurophysiology, University of Copenhagen, and the Laboratory of Clinical \\ Neurophysiology, Rigshospitalet, Copenhagen, Denmark
}

SUMMARY For comparison with findings in neuropathy, sensory conduction was studied along distal and proximal segments of the superficial peroneal, sural, and posterior tibial nerves in 71 healthy subjects 15 to 72 years of age and normal values were established (Table 2). In the distal segments of the nerves of the leg the amplitudes of the sensory potentials were one tenth those in the nerves of the upper extremity; the potentials were split up into several components, and electronic averaging was used routinely to analyse the shape of the potentials. The maximum sensory conduction velocity was $56.5 \mathrm{~m} / \mathrm{sec}$, SD $3.4 \mathrm{~m} / \mathrm{sec}$, in proximal; and $46.1 \mathrm{~m} / \mathrm{sec}$, SD $3.7 \mathrm{~m} / \mathrm{sec}$, in distal segments of the nerves (subjects 15 to 30 years, 34 to $36^{\circ} \mathrm{C}$ ). Slowing of conduction with increasing age was the same proximally and distally (subjects 40 to 65 years: proximally $53 \cdot 1 \mathrm{~m} / \mathrm{sec}_{2}$ SD $4.6 \mathrm{~m} / \mathrm{sec}$; distally $42.5 \mathrm{~m} / \mathrm{sec}$, SD $5.5 \mathrm{~m} / \mathrm{sec}, 34$ to $36^{\circ} \mathrm{C}$ ). The velocity in the slowest components of the sensory potentials averaged $20 \mathrm{~m} / \mathrm{sec}$. The sensory velocity was 3 to $6 \mathrm{~m} / \mathrm{sec}$ faster than the motor. The error arising from measuring the conduction distance on the surface across the capitulum fibulae was evaluated.

Sensory conduction has most often been measured in the nerves of the upper extremity. Gilliatt, Goodman, and Willison (1961) were the first to record sensory potentials in the leg, from the lateral popliteal nerve at the capitulum fibulae. The amplitude of the sensory potentials was of the order of 1 to $3 \mu \mathrm{V}$, less than a third as large as in the proximal segments of the nerves of the upper extremities. The sensory potentials of distal segments of the nerves of the leg were often buried in noise (Mayer, 1963; Downie and Scott, 1967; Ertekin, 1969) and electronic averaging was necessary to record the potentials (Buchthal and Rosenfalck, 1966; Mavor and Atcheson, 1966; Sato, 1967; Shiozawa and Mavor, 1968; Lovelace, Myers, and Zablow, 1969).

The purpose of the study presented in this report was to record sensory potentials along the superficial peroneal, sural, and posterior tibial nerves with improved resolution by recording close to the nerve, by using a special input circuit (Buchthal and Rosenfalck, 1966) and by electronic averaging. In this way, maximum and minimum conduction velocities were determined along distal and proximal segments of the nerves in young and old subjects and the shape of the potentials could be evaluated.

METHOD

\section{A. GENERAL}

1. POSITIONING OF SUBJECT When the peroneal nerve was investigated, the subject lay supine with the knee bent at $120^{\circ}$; when the posterior tibial and sural nerves were studied the subject lay prone with a support under the ankle to bend the knee to an angle of $140^{\circ}$.

2. stimulus The stimulus was a rectangular pulse, 0.2 음 msec in duration, delivered from a double-screened 3 transformer or a constant-current stimulator isolated $\dot{\phi}$ from ground. The stimulus current was recorded on $\frac{9}{3}$ one channel of the electromyograph (Disa 14A30) (Buchthal and Rosenfalck, 1966). Surface ring electrodes 음 were placed on the big toe, and lead plates $5 \mathrm{~mm}$ in $\square$ diameter on the dorsum of the foot. Stimulation at other sites was through the needle electrodes placed near the $N$ nerve. A maximum response was obtained by a current of $O$ 50 to $70 \mathrm{~mA}$ to the big toe, of 10 to $20 \mathrm{~mA}$ to the dorsum N of the foot, and of 6 to $12 \mathrm{~mA}$ through needle electrodes near the nerve. 
3. RECORDING ELECTRODES The near-nerve electrode was an insulated needle, $0.7 \mathrm{~mm}$ in diameter, with a bared tip of $3 \mathrm{~mm}$; the remote electrode had a bared tip of $5 \mathrm{~mm}$ and was placed at a transverse distance of 2 to 4 $\mathrm{cm}$ from the near-nerve electrode. When recording from purely sensory nerves the electrode was placed near the nerve by adjusting its position to the point of maximal response. When the nerve also contained motor fibres the threshold of the muscle action potential of 0.5 to $1 \mathrm{~mA}$ indicated that the electrode was near the nerve.

The muscle action potentials were recorded with concentric electrodes placed in the endplate zone. The sensory potentials were recorded via an input transformer (transformer ratio $1: 10$ ) and an amplifier with a short blocking time, a lower limiting frequency of $20 \mathrm{~Hz}$, and an upper limiting frequency of $4 \times 10^{3} \mathrm{~Hz}(3 \mathrm{db}$ down). The stimulus artefact was compensated by a pulse of the same shape and opposite sign, inserted in series with the recording electrodes (Andersen and Buchthal, 1970).

Single sweeps, photographic superposition of 20 responses or, when the responses were less than $2 \mu \mathrm{V}$, electronic averaging of 300 to 500 responses were used for recording. The averager had 400 'points' and a clockcontrolled adjustable delay such that the number of 'points' was the same independent of the conduction distance.

The slowest components of the sensory potentials had amplitudes of 0.05 to $0.1 \mu \mathrm{V}$ and were accepted only when they could be distinguished from noise by their shape and amplitude in two successive recordings.

4. CONTROL OF TEMPERATURE A thermocouple placed on the volar or dorsal surface of the leg controlled a source of radiant heat automatically to maintain a surface temperature of 36 to $37^{\circ} \mathrm{C}$, corresponding to 34 to $35^{\circ} \mathrm{C}$ near the nerve.

5. MEASUREMENT The shortest latency of the sensory action potential was measured to the first positive peak; that of the slowest components to the positive peak of the last component discriminated by electronic averaging. The motor latency was measured to the initial deflection from the base line of the muscle action potential and was corrected to a standard distance by means of the proximal conduction velocity (Slomić, Rosenfalck, and Buchthal, 1968 , p. 23). The amplitudes were measured peak-topeak. The $95 \%$ lower limits of conduction velocity and amplitude and the upper limit of distal motor latency were determined from plots of the cumulative distribution functions.

\section{B. SITES OF STIMULATION AND RECORDING}

1. SUPERFICIAL PERONEAL NERVE a. Distal velocity between the big toe and the dorsum of the ankle 2 to $3 \mathrm{~cm}$ proximal to a line connecting the malleoli 1 to $2 \mathrm{~cm}$ lateral to the tendon of the anterior tibial muscle ('superior extensor retinaculum'): the near-nerve electrode was placed at the medial branch of the nerve ( $N$. cutaneus pedis dorsalis medialis). When the nerve could not be palpated, the site of insertion was found by stimulating with a surface electrode. b. Proximal velocity from the superior extensor retinaculum to about $1 \mathrm{~cm}$ below the capitulum fibulae: the electrode at the capitulum fibulae was placed near the superficial peroneal nerve by adjusting its position until the threshold of the long peroneal muscle was below 1 $\mathrm{mA}$, and lower than that of the anterior tibial muscle.

A concentric needle electrode was placed in the extensor digitorum brevis muscle to ascertain that the stimulus at the superior retinaculum did not activate the deep peroneal nerve or a separate branch to the muscle (Lambert, 1969; Infante and Kennedy, 1970).

c. To determine the velocity across the capitulum fibulae a recording electrode was placed in the popliteal fossa medial to the tendon of the biceps femoris muscle, 9.5 to $12.5 \mathrm{~cm}$ proximal to the electrode below the capitulum fibulae. The remote electrode was placed laterally. Supramaximal stimulation of the common peroneal nerve in the popliteal fossa without excitation of the posterior tibial nerve is possible in this way and, unlike the method of Jimenez, Easton, and Redfort, (1970), interference by the responses of the extensor digitorum brevis muscle with those of other intrinsic foot muscles is avoided.

As long as the segment of the nerve across the capitulum fibulae did not exceed $12.5 \mathrm{~cm}$, the length measured on the surface (the leg maximally extended) corresponded to the true length of the nerve. This was shown by comparing the distance measured on the surface with that along the exposed nerve (Table 1).

2. SURAL NERVE a. Distal velocity between the lateral aspect of the foot ('dorsum pedis') and the lateral malleolus (Fig. 1): the stimulating electrodes were placed on the dorsal aspect of the foot, at least $2 \mathrm{~cm}$ distal to the border of the extensor digitorum brevis muscle, because it was often difficult to attach the electrodes to the little toe. With a stimulus of 10 to $20 \mathrm{~mA}$ the response was maximal; a stimulus of more than $20 \mathrm{~mA}$ activated the intrinsic muscles of the foot, and their action potential interfered with the sensory potential (Fig. 2).

\section{TABLE 1}

DISTANCE FROM BELOW CAPITULUM FIBULAE TO POPLITEAL FOSSA MEASURED ON SURFACE OF SKIN AND ALONG NERVE (SIX CADAVERS)

\begin{tabular}{|c|c|c|c|c|c|}
\hline \multirow{2}{*}{$\begin{array}{l}\text { Age } \\
(y r)\end{array}$} & \multirow[t]{2}{*}{ Sex } & \multicolumn{2}{|c|}{ Distance $(\mathrm{cm})$} & \multicolumn{2}{|c|}{ Depth of nerve $(\mathrm{cm})$} \\
\hline & & Surface & Nerve & $\begin{array}{c}\text { Below capitulum } \\
\text { fibulae }\end{array}$ & $\begin{array}{l}\text { Popliteal } \\
\text { fossa }\end{array}$ \\
\hline 57 & $\mathbf{M}$ & $\begin{array}{r}8 \cdot 5 \\
11 \cdot 3 \\
14 \cdot 0\end{array}$ & $\begin{array}{r}8 \cdot 4 \\
11 \cdot 3 \\
14 \cdot 1\end{array}$ & 0.7 & $\begin{array}{l}1 \cdot 5 \\
2 \cdot 3 \\
2 \cdot 4\end{array}$ \\
\hline 47 & $\mathbf{M}$ & $\begin{array}{r}9.6 \\
11.9 \\
14.4\end{array}$ & $\begin{array}{r}9.7 \\
12.0 \\
14.8\end{array}$ & 0.6 & $\begin{array}{l}1 \cdot 3 \\
1 \cdot 8 \\
2 \cdot 2\end{array}$ \\
\hline 67 & $\mathbf{M}$ & $\begin{array}{l}10 \cdot 1 \\
12 \cdot 4 \\
15 \cdot 0\end{array}$ & $\begin{array}{l}10 \cdot 1 \\
12 \cdot 3 \\
14 \cdot 1\end{array}$ & 0.9 & $\begin{array}{l}1 \cdot 9 \\
2 \cdot 1 \\
3 \cdot 1\end{array}$ \\
\hline 60 & $\mathbf{F}$ & 12.6 & 13.6 & 0.8 & $2 \cdot 2$ \\
\hline 45 & $\mathbf{M}$ & $11 \cdot 5$ & 116 & 0.7 & $1 \cdot 8$ \\
\hline 68 & $\mathbf{M}$ & $12 \cdot 0$ & $12 \cdot 1$ & 0.6 & 1.6 \\
\hline
\end{tabular}




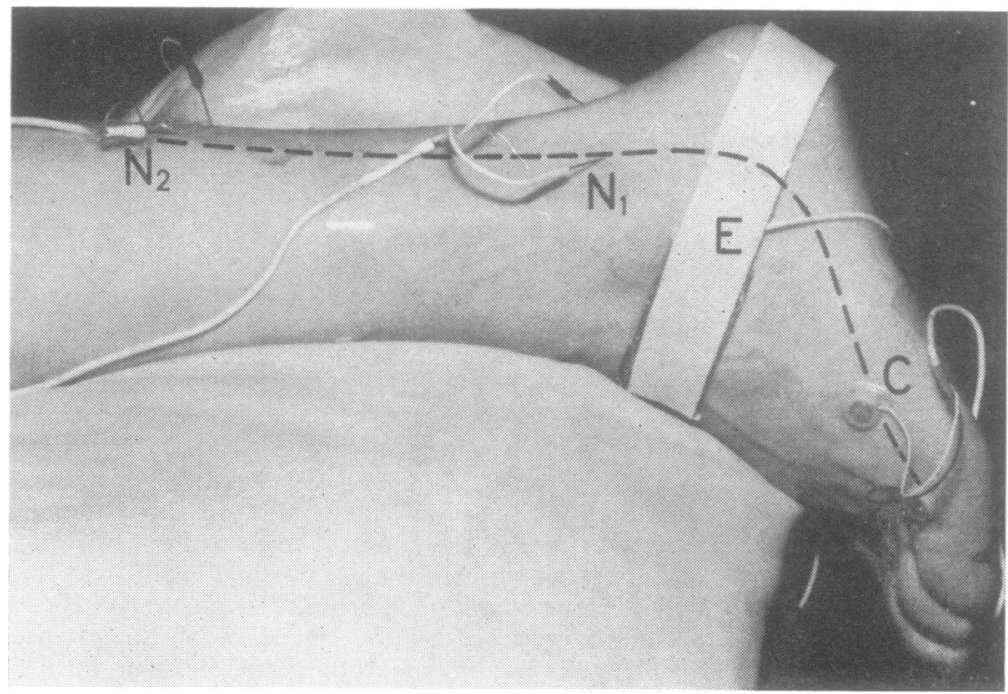

FIG. 1. Placement of stimulating and recording electrodes near the sural nerve. $\mathrm{C}$ : stimulating cathode, E: earth electrode, $N_{1}$ : near-nerve electrode at the lateral malleolus, $\mathrm{N}_{2}$ : at the sura.

When the sural nerve could not be palpated at the lateral malleolus, the recording electrode was adjusted by applying a weak stimulus through it and by searching for the largest response at a more proximal point of recording. The remote electrode was placed subcutaneously above the Achilles tendon. Recording at the lateral malleolus was often associated with a large stimulus artefact, which could be reduced by displacing the remote electrode by 2 to $3 \mathrm{~mm}$ proximally or distally. b. Proximal velocity recorded $15 \mathrm{~cm}$ proximal to the lateral malleolus ('sura'): when the nerve could not be palpated just lateral to the Achilles tendon, the electrod was placed near the nerve by the maximum responso obtained to a stimulus at the malleolus. The remote electrode was placed medially $3 \mathrm{~cm}$ from the near-nerve electrode. This avoided pick-up by the remote electrodg from the lateral cutaneous branch of the nerve ( cutaneus surae lateralis).

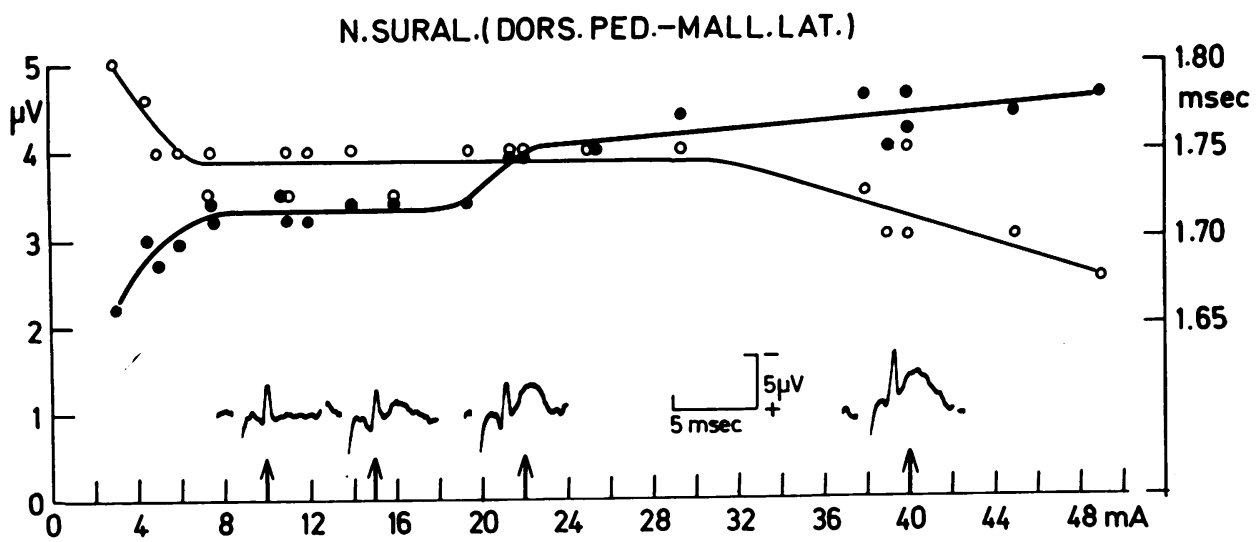

FIG. 2. Response amplitude ( $\mu \mathrm{V}$, left ordinate) and latency (msec, right ordinate) of the potentials recorded from the sural nerve at the later al malleolus, stimuli applied to the dorsal aspect of the foot, as a function of the strength of the stimuli ( $m A$, abscissa). Subject S.H., male, 18 years old (temperature on the skin 35 to $37^{\circ} \mathrm{C}$ ). The response amplitude and the latency reached level at $8 \mathrm{~mA}$. The increase in amplitude which occurred above $20 \mathrm{~mA}$ was due to superposition by the muscle action potential (seen from the samples of sensory potentials below). The decrease in latency above $30 \mathrm{~mA}$ was presumably due to proximal displacement of the point of stimulation relative to the stimulating cathode. $\bigcirc-\bigcirc$ Latency to the initial positive peak. 
c. Proximal velocity recorded at the popliteal fossa: to ensure that the electrode was situated proximal to the junction of the fibres of the sural nerve with the posterior tibial nerve, the near-nerve electrode was placed 4 to 5 $\mathrm{cm}$ proximal to the skin fold in the middle of the popliteal fossa and adjusted to a threshold below $1 \mathrm{~mA}$ for the action potential of the lateral belly of the gastrocnemius muscle.

3. POSTERIOR TIBIAL NERVE $a$. Distal velocity from the big toe to the medial malleolus: The near-nerve electrode was adjusted by means of the threshold of the action potential of the abductor hallucis brevis muscle; the remote electrode was placed above the Achilles tendon.

b. The proximal velocity was recorded in the popliteal fossa, the near-nerve electrode located as described (2 c). In addition the mixed nerve was stimulated at the medial malleolus and the potential recorded in the popliteal fossa.

\section{MATERIAL}

Seventy-one subjects without signs or symptoms of neuromuscular diseases were examined; 53 were males and 18 females. Thirty-four were between 15 and 33 years, 37 were 40 to 72 years old. The peroneal, sural, and posterior tibial nerves were investigated in 20 persons, two of these nerves in 20 , and one in 31 subjects.

\section{RESULTS}

1. CONDUCTION VELOCITY IN SENSORY FIBRES The maximal velocity along the superficial peroneal, sural, and posterior tibial nerves was the same in the proximal segment of the nerves $(P>0 \cdot 1)$, as was the distal velocity along the peroneal and posterior tibial nerves $(P>0.5)$. The distal velocity was $10 \mathrm{~m} / \mathrm{sec}$ slower than the proximal $(P<0.001)$. In the sural nerve, the distal velocity was only $6 \mathrm{~m} / \mathrm{sec}$ slower than the proximal $(\mathrm{P}<0.001$ to $\mathrm{P}<0.02)$ because the stimulus was applied to the dorsal aspect of the foot instead of to the little toe. With increasing age of the subjects the distal and proximal velocities decreased equally, about $1 \mathrm{~m} / \mathrm{sec}$ per 10 years of age (Fig. 3), the velocity at 15 to 30 yrs being 3 to 4 $\mathrm{m} / \mathrm{sec}$ faster than at 40 to 65 yrs $(P<0.005$ to $\mathbf{P}<0.001)$. Mean values of maximum sensory conduction velocity and examples of sensory potentials

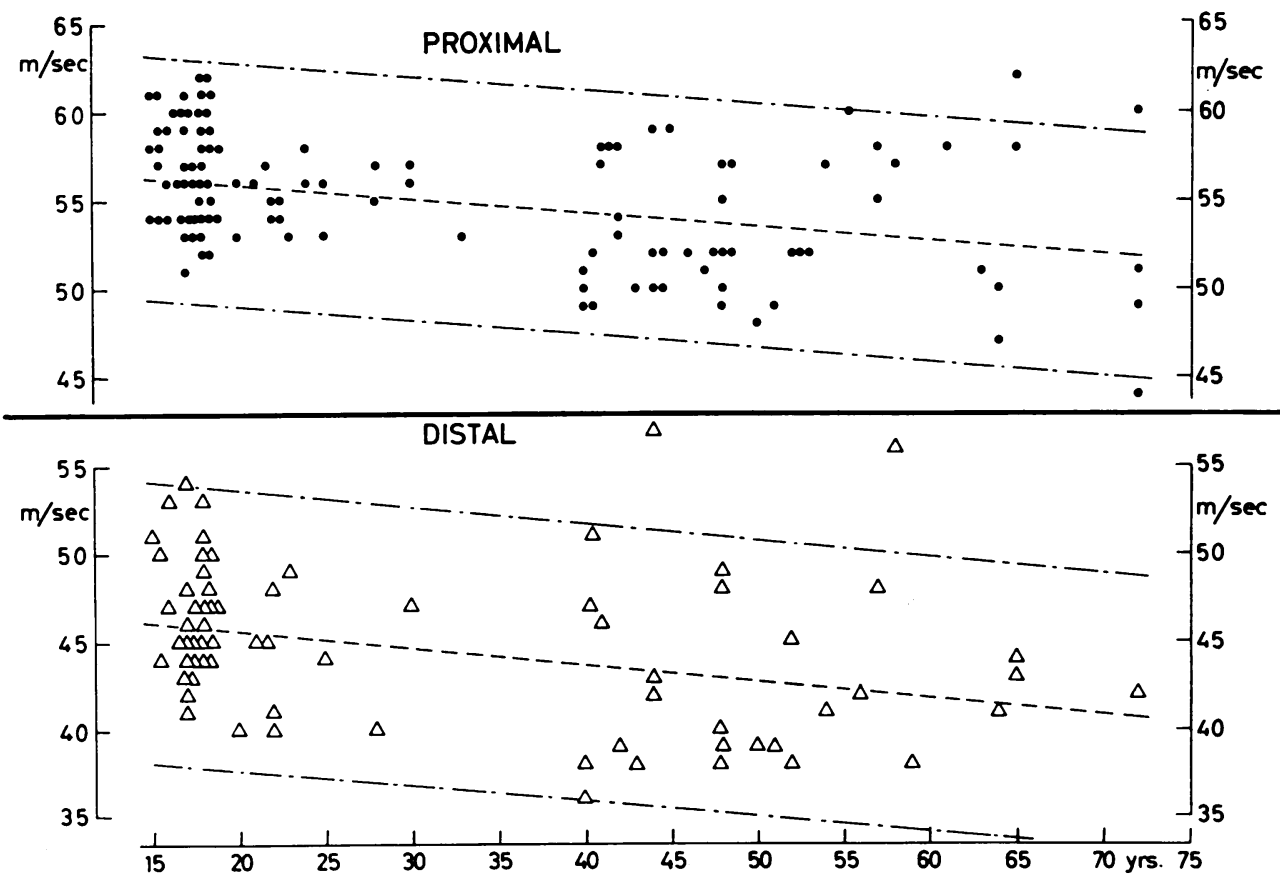

FIG. 3. Maximum conduction velocity along sensory fibres as a function of age (71 subjects, temperature on the skin 35 to $37^{\circ} \mathrm{C}$ ). Proximal segment, superficial peroneal, sural and posterior tibial nerve; $\triangle$ Distal segment, superficial peroneal and posterior tibial nerve. The regression lines (dashed) show a decrease in conduction velocity of about $1 \mathrm{~m} / \mathrm{sec}$ per 10 years of age (b proximal $=-0.08 \pm 0.02$ $\mathrm{m} / \mathrm{sec}$ per year, $\mathrm{P}<0.001 ; b$ distal $=-0.10 \pm 0.03 \mathrm{~m} / \mathrm{sec}$ per year, $\mathrm{P}<0.005)$. The stippled lines give the range containing $95 \%$ of the values. 
at the different sites of recording in each nerve are given in Table 2 and Figs. 4, 5, and 6. The proximal velocity was the same whether it was determined from the stimulating cathode to the proximal electrode or calculated by subtracting the distal velocity, indicating that the displacement of the point of stimulation from the stimulating cathode was negligible.

The velocity of the slowest components was 20 $\mathrm{m} / \mathrm{sec}$, the same when recorded along the distal segments, at sura and at capitulum fibulae $(P>0.3)$ (Fig. 7). Only the minimum velocity between the big toe and the popliteal fossa was somewhat faster $(26 \mathrm{~m} / \mathrm{sec} ; \mathrm{P}<0.001)$.

2. AMPLITUDES OF THE SENSORY POTENTIALS (Table 3) The potential amplitudes were smaller in older than in younger subjects. In the distal segments, they were lowest in the superficial peroneal nerve, about three times larger in the posterior tibial, and largest in the sural nerve. At more proximal points of recording the potentials were much smaller when the nerve was stimulated at the big toe or the dorsum pedis than when it was stimulated at the level of the malleoli. Sensory potentials in the superficial peroneal nerve evoked by stimulation of toe II, III, or IV had the same amplitudes as when the big toe was stimulated.

The potentials were split up in many components at distal and proximal sites of recording except at sura, when the stimulus was applied at the level of the lateral malleolus. The slowest components which could be recorded reproducibly were 0.05 to $0.1 \mu \mathrm{V}$.

3. CONDUCTION VELOCITY IN MOTOR FIBRES In the proximal segment the motor conduction velocity was the same in the deep peroneal as in the posterior tibial nerve $(P<0.4)$ (Table 4$)$, but 5 to $6 \mathrm{~m} / \mathrm{sec}$ slower than the velocity in sensory fibres of the superficial peroneal and posterior tibial nerves $(P<0.001$ to $P<0.02)$ and of the mixed nerve when the stimulus was applied to the medial malleolus $(\mathrm{P}<0.001)$.

Between the popliteal fossa and the capitulum fibulae the velocity was 6 to $8 \mathrm{~m} / \mathrm{sec}$ faster in the fibres to the long peroneal than to the extensor digitorum brevis muscle $(P<0.001$ to $P<0.01)$ and tended to be faster than in the sensory fibres in

TABLE 2

MAXIMUM SENSORY CONDUCTION VELOCITY IN DISTAL AND PROXIMAL SEGMENTS OF SUPERFICIAL PERONEAL, SURAL, AND POSTERIOR TIBIAL NERVE IN 34 SUBJECTS 15 TO 33 YEARS, AND 37 SUBJECTS 40 TO 65 YEARS OLD

(TEMPERATURE ON SKIN 35 to $37^{\circ} \mathrm{C}$ )

\begin{tabular}{|c|c|c|c|c|c|c|c|c|c|}
\hline \multirow[t]{2}{*}{ Segment } & \multirow[t]{2}{*}{$\begin{array}{l}\text { Age } \\
(y r)\end{array}$} & \multirow[t]{2}{*}{$n^{1}$} & \multicolumn{3}{|c|}{$\stackrel{A}{\text { Conduction velocity }(\mathrm{m} / \mathrm{sec})}$} & \multirow[t]{2}{*}{$n^{1}$} & \multicolumn{3}{|c|}{ Conduction velocity $(\mathrm{m} / \mathrm{sec})$} \\
\hline & & & mean & $95 \%$ & $S D$ & & mean & $95 \%$ & $S D$ \\
\hline $\begin{array}{l}\text { N. peroneus superficiali } \\
\text { Big toe- } \\
\text { sup. ext. retinac. } \\
\text { Sup. ext. retinac. } \\
\text {-capitul. fibul. } \\
\text { Sup. ext. retinac. } \\
\text {-poplit. fossa } \\
\text { Capitul. fibul. } \\
\text {-poplit. fossa }\end{array}$ & $\begin{array}{l}15-25 \\
40-65 \\
15-33 \\
40-65 \\
15-30 \\
40-65 \\
15-25 \\
40-65\end{array}$ & $\begin{array}{l}19 \\
17 \\
24 \\
23 \\
15 \\
11\end{array}$ & $\begin{array}{l}46 \cdot 1 \\
42.2 \\
55 \cdot 9 \\
52.9 \\
56.3 \\
53.0\end{array}$ & $\begin{array}{l}39.0 \\
36 \cdot 0 \\
50 \cdot 0 \\
47.0 \\
50.0 \\
48.0\end{array}$ & $\begin{array}{l}4 \cdot 1 \\
6 \cdot 3 \\
3 \cdot 8 \\
3 \cdot 7 \\
3 \cdot 7 \\
2 \cdot 9\end{array}$ & $\begin{array}{l}13 \\
11\end{array}$ & $\begin{array}{l}55 \cdot 8 \\
53 \cdot 5\end{array}$ & $\begin{array}{l}47 \cdot 0 \\
46 \cdot 0\end{array}$ & $\begin{array}{l}4 \cdot 7 \\
5 \cdot 2\end{array}$ \\
\hline $\begin{array}{l}\text { N. suralis } \\
\text { Dors. ped.- } \\
\text { lat. malleol. } \\
\text { Lat. malleol. } \\
\text {-sura } \\
\text { Lat. malleol. } \\
\text {-poplit. fossa } \\
\text { Sura- } \\
\text { poplit. fossa }\end{array}$ & $\begin{array}{l}15-30 \\
40-65 \\
15-30 \\
40-65 \\
15-30 \\
40-65 \\
15-30 \\
40-65\end{array}$ & $\begin{array}{l}16 \\
15 \\
21 \\
16 \\
19 \\
12\end{array}$ & $\begin{array}{l}51 \cdot 2 \\
48 \cdot 3 \\
56 \cdot 5 \\
54 \cdot 8 \\
57 \cdot 3 \\
53 \cdot 3\end{array}$ & $\begin{array}{l}42 \cdot 0 \\
40 \cdot 0 \\
51 \cdot 0 \\
46 \cdot 5 \\
52 \cdot 0 \\
47.5\end{array}$ & $\begin{array}{l}4 \cdot 5 \\
5 \cdot 3 \\
3 \cdot 4 \\
4 \cdot 5 \\
3 \cdot 5 \\
4 \cdot 1\end{array}$ & $\begin{array}{r}16 \\
12 \\
18 \\
10\end{array}$ & $\begin{array}{l}55 \cdot 9 \\
56 \cdot 3\end{array}$ & $\begin{array}{l}49 \cdot 0 \\
47 \cdot 0\end{array}$ & $\begin{array}{l}4 \cdot 2 \\
5 \cdot 5\end{array}$ \\
\hline $\begin{array}{l}\text { N. tibialis posterior } \\
\text { Big toe- } \\
\text { med. malleol. } \\
\text { Med. malleol. } \\
\text {-poplit. fossa }\end{array}$ & $\begin{array}{l}15-30 \\
40-65 \\
15-30 \\
40-52\end{array}$ & $\begin{array}{r}23 \\
10 \\
17 \\
7\end{array}$ & $\begin{array}{l}46 \cdot 1 \\
43 \cdot 4 \\
58 \cdot 6^{2} \\
57 \cdot 4^{2}\end{array}$ & $\begin{array}{l}39 \cdot 0 \\
37 \cdot 0 \\
52 \cdot 5 \\
51 \cdot 5\end{array}$ & $\begin{array}{l}3 \cdot 5 \\
3 \cdot 8 \\
3 \cdot 8 \\
4 \cdot 5\end{array}$ & $\begin{array}{r}22 \\
6\end{array}$ & $\begin{array}{l}56.4 \\
54.0\end{array}$ & $\begin{array}{l}51.0 \\
47.0\end{array}$ & $\begin{array}{l}4.0 \\
4.4\end{array}$ \\
\hline
\end{tabular}

A: calculated from the latency measured between onset of the stimulus and the initial peak of the sensory potential.

B: calculated from the difference of latencies, measured at two sites of recording.

Number of nerves

${ }^{2}$ Conduction velocity in fibres of mixed nerve. 


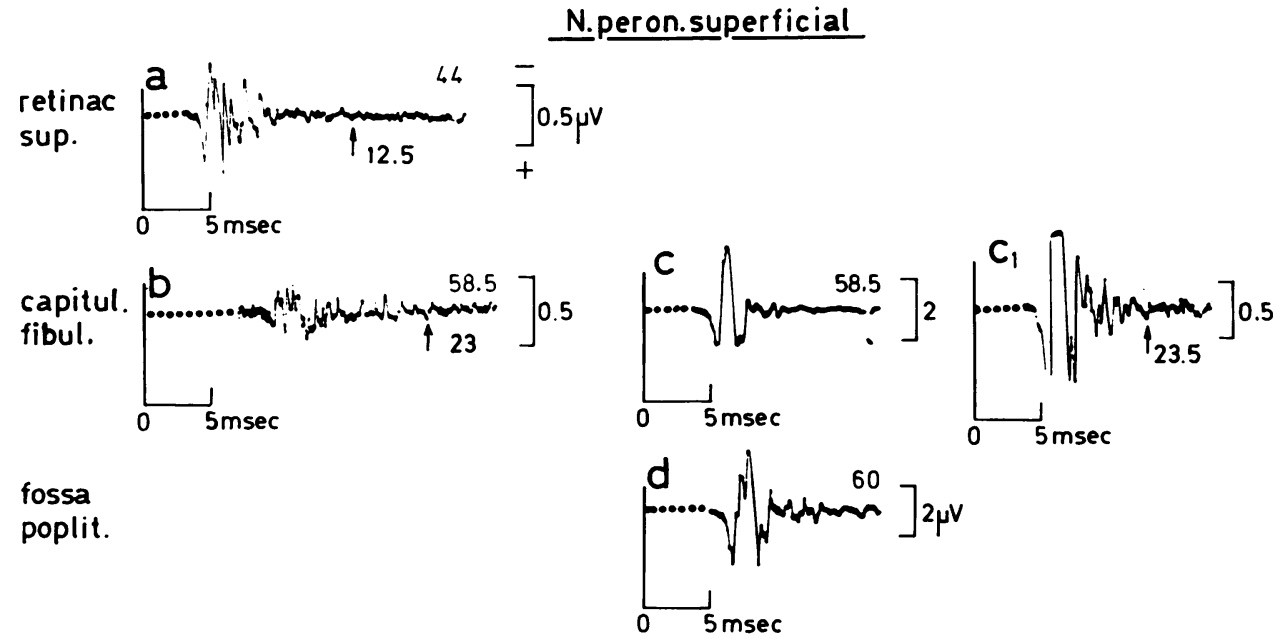

FIG. 4. Sensory potentials evoked by supramaximal stimuli to the big toe $(60 \mathrm{~mA}, \mathrm{a}, \mathrm{b})$, at the superior extensor retinaculum ( $9 \mathrm{~mA}, \mathrm{c}, \mathrm{d} ; \mathrm{c}_{1}$ as $\mathrm{c}$ but with higher amplification) and recorded at the sites given to the left. Electronic averaging of 500 responses with the same number of points per unit time. The use of a delay before sampling is indicated by the stippled lines. The figures above the traces give the maximum conduction velocity $(\mathrm{m} / \mathrm{sec})$ in the segment of the nerve distal to the point of recording; the figures below the traces give the minimum conduction velocity $(\mathrm{m} / \mathrm{sec})$ from the stimulating cathode (arrows at slowest reproducible components). Subject J.J., male, 16 years old (temperature on the skin 35 to $37^{\circ} \mathrm{C}$ ).

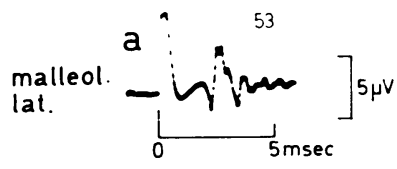

N.suralis
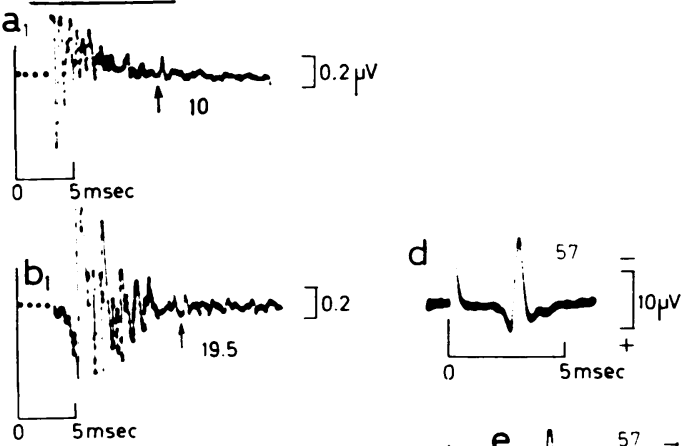

sura

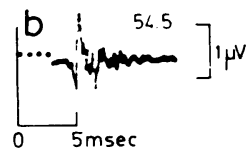

62
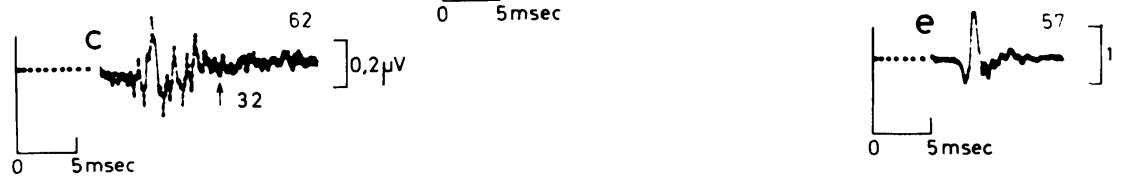

FIG. 5. Sensory potentials evoked by supramaximal stimuli at the laterodorsal aspect of the foot (20 $\mathrm{mA}, \mathrm{a}, \mathrm{b}, \mathrm{c} ; \mathrm{a}_{1}$ as $\mathrm{a}$ and $\mathrm{b}_{1}$ as $\mathrm{b}$ but with higher amplification) and at the lateral malleolus $(12 \mathrm{~mA}$, $\mathrm{d}, \mathrm{e})$ and recorded at the sites given to the left. Photographic superposition of 20 responses (a, d) and electronic averaging of 500 responses with the same number of points per unit time $\left(\mathrm{a}_{1}, \mathrm{~b}, \mathrm{~b}_{1}, \mathrm{c}, \mathrm{e}\right)$. The use of a delay before sampling is indicated by the stippled lines. The figures above the traces give the maximum conduction velocity $(\mathrm{m} / \mathrm{sec})$ in the segment of the nerve distal to the point of recording; the figures below the traces give the minimum conduction velocity $(\mathrm{m} / \mathrm{sec})$ from the stimulating cathode. Subject J.J., male, 16 years old (temperat ure on the skin 35 to $37^{\circ} \mathrm{C}$ ). 

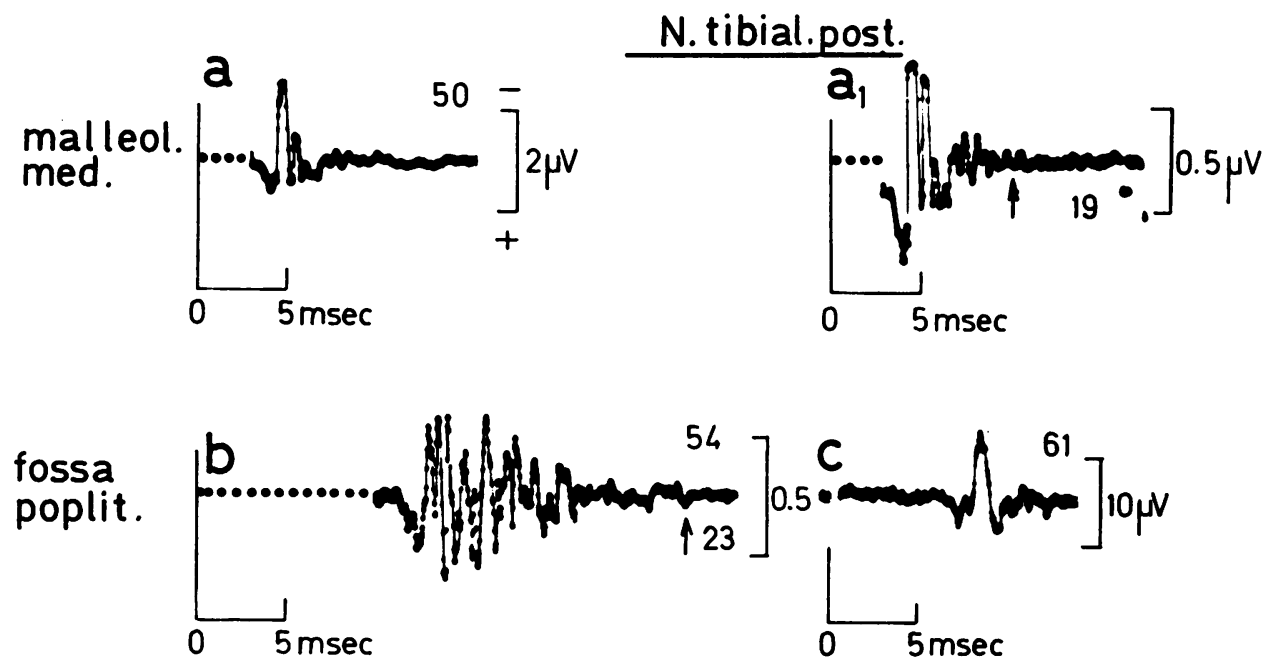

FIG. 6. Sensory potentials evoked by supramaximal stimuli to the big toe $\left(80 \mathrm{~mA}, \mathrm{a}, \mathrm{b} ; \mathrm{a}_{1}\right.$ as a but with higher amplification), mixed nerve potential (c) evoked by supramaximal stimuli $(8 \mathrm{~mA})$ at the medial malleolus and recorded at the sites given to the left. Single response (c) or electronic averaging of 500 responses $\left(\mathrm{a}_{\mathrm{a}} \mathrm{a}_{1}, \mathrm{~b}\right)$ with the same number of points per unit time. The use of a delay before sampling is indicated by the stippled lines. The figures above the traces give the maximum conduction velocity $(\mathrm{m} / \mathrm{sec})$ in the segment of the nerve distal to the site of recording; the figures below the traces give the minimum conduction velocity $(\mathrm{m} / \mathrm{sec})$ from the stimulating cathode (arrows at slowest reproducible components). Subject J.J., male, 16 years old (temperature on the skin 35 to $37^{\circ} \mathrm{C}$ ).

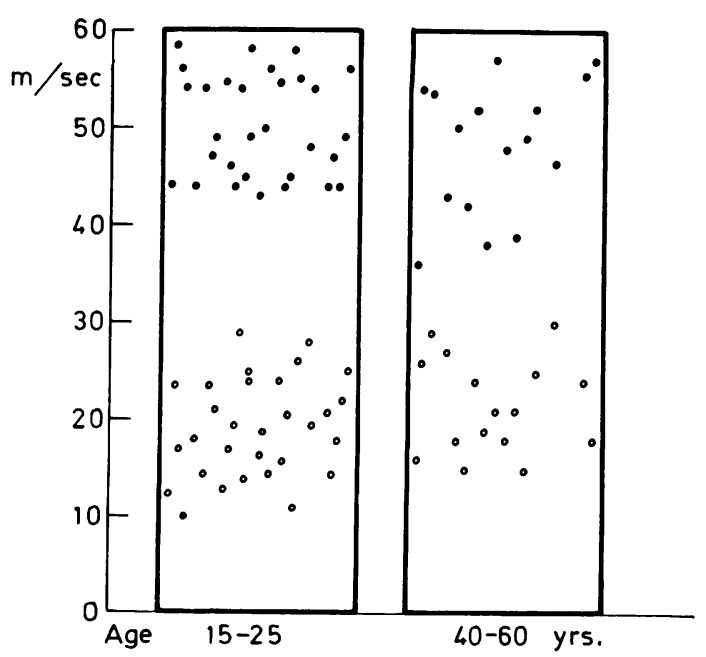

FIG. 7. Maximum (O) and minimum ( $\bigcirc)$ conduction velocity in the superficial peroneal, sural, and posterior tibial nerve in 31 subjects aged 15 to 25 years and in 16 subjects aged 40 to 60 (temperature on the skin 35 to $37^{\circ} \mathrm{C}$ ). Sensory potentials recorded at the superior extensor retinaculum and capitulum fibulae (superficial peroneal nerve), at the lateral malleolus and sura (sural nerve), and at the medial malleolus (posterior tibial nerve). the corresponding segment $(\mathrm{P}<0.05$ in the young and $P>0.25$ in the older subjects) (Table 5). Along the fibres to the extensor digitorum brevis muscle the velocity across the capitulum was about $50 \mathrm{~m} / \mathrm{sec}$, similar to that found by Jiminez et al. (1970). The latency to proximal muscles (long peroneal and gastrocnemius) was shorter than the distal latency to the extensor digitorum brevis and the abductor hallucis brevis muscles, when corrected to the same distance of conduction (Table 6).

The conduction velocity across the capitulum fibulae is of interest, because this segment of the peroneal nerve is apt to be affected by local compression. In normal subjects the conduction velocity across the capitulum fibulae was the same as distal to it. When the nerve is compressed at the capitulum fibulae, the conduction velocity from the popliteal fossa to the ankle may still be within the normal range, but significantly slowed when measurement is confined to the segment from the popliteal fossa to the capitulum fibulae (Fig. 8).

The mean amplitudes of the muscle action potentials were 10 to $25 \mathrm{mV}$, largest in the gastrocnemius muscle. The corresponding lower limits of the normal range were 3 to $9 \mathrm{mV}$.

In five of 30 subjects $(16 \%)$ the action potential of the extensor digitorum brevis muscle was larger 
TABLE 3

AMPLITUDE OF SENSORY POTENTIALS AT DISTAL AND PROXIMAL SITES OF SUPERFICIAL PERONEAL, SURAL, AND POSTERIOR TIBIAL NERVE IN 34 SUBJECTS 15 TO 30 YEARS AND 37 SUBJECTS 40 TO 65 YEARS OLD (TEMPERATURE ON SKIN 35 TO $37^{\circ} \mathrm{C}$ )

\begin{tabular}{|c|c|c|c|c|c|c|c|c|c|c|c|c|c|}
\hline \multirow[t]{2}{*}{ Nerve } & \multirow{2}{*}{$\begin{array}{l}\text { Age } \\
(y r)\end{array}$} & \multicolumn{4}{|c|}{ Amplitude $(\mu V)$} & \multicolumn{4}{|c|}{ Amplitude $(\mu V)$} & \multicolumn{4}{|c|}{ Amplitude $(\mu V)$} \\
\hline & & $n^{1}$ & mean & $95 \%$ & $S D$ & $n^{1}$ & mean & $95 \%$ & $S D$ & $n^{1}$ & mean & $95 \%$ & $S D$ \\
\hline \multirow[t]{3}{*}{ N. peron. superfic. } & & \multicolumn{4}{|c|}{ Big toe - sup. ext. retinaz. } & \multicolumn{4}{|c|}{ Sup. ext. retinac. - capitul. fibul. } & \multicolumn{4}{|c|}{ Sup. ext. retinac. - poplit. fossa } \\
\hline & $15-30$ & 19 & $1 \cdot 2$ & $0 \cdot 1$ & 0.9 & 24 & $4 \cdot 1$ & 1.2 & $2 \cdot 3$ & 13 & $3 \cdot 1$ & 0.8 & 1.8 \\
\hline & $40-65$ & 17 & 0.5 & 0.0 & $0 \cdot 4$ & 23 & $3 \cdot 8$ & 0.7 & $2 \cdot 1$ & 11 & $3 \cdot 6$ & $1 \cdot 3$ & 1.6 \\
\hline \multirow[t]{6}{*}{ N. suralis } & & \multicolumn{4}{|c|}{ Dors. ped. - lat. malleol } & \multicolumn{4}{|c|}{ Dors. ped. - sura } & \multicolumn{4}{|c|}{ Dors. ped. - poplit. fossa } \\
\hline & $15-30$ & 16 & $5 \cdot 5$ & $2 \cdot 0$ & $2 \cdot 9$ & 16 & 1.8 & 0.5 & 1.0 & 8 & $1 \cdot 1$ & 0.2 & 0.6 \\
\hline & $40-65$ & 15 & 3.9 & 0.5 & $3 \cdot 3$ & 12 & 1.6 & $0 \cdot 3$ & $1 \cdot 3$ & & & & \\
\hline & & & & & & \multicolumn{4}{|c|}{ Lat. maelleol. - sura } & \multicolumn{4}{|c|}{ Lat. malleol. - poplit. fossa } \\
\hline & $15-30$ & & & & & 21 & $12 \cdot 6$ & $3 \cdot 5$ & $5 \cdot 4$ & 18 & $3 \cdot 8$ & 1.5 & 1.5 \\
\hline & $40-65$ & & & & & 16 & $7 \cdot 7$ & $3 \cdot 0$ & $3 \cdot 4$ & 10 & $2 \cdot 0$ & $0 \cdot 1$ & $1 \cdot 5$ \\
\hline \multirow[t]{3}{*}{ N. tibial. post. } & & \multicolumn{4}{|c|}{ Big toe - med. malleol. } & \multicolumn{4}{|c|}{ Big toe - poplit. fossa } & Med. & malleol. & - poplit. & fossa $a^{2}$ \\
\hline & $15-30$ & 23 & $3 \cdot 6$ & 0.5 & $2 \cdot 6$ & 22 & $1 \cdot 2$ & 0.1 & $1 \cdot 0$ & 17 & $18 \cdot 0$ & 5.0 & $10 \cdot 2$ \\
\hline & $40-65$ & 10 & 1.6 & 0.2 & 1.8 & 6 & 0.8 & $0 \cdot 1$ & 0.6 & 7 & 9.9 & 1.0 & $4 \cdot 6$ \\
\hline
\end{tabular}

${ }^{1}$ Number of nerves.

2Potential of mixed nerve.

when the peroneal nerve was stimulated at the capitulum fibulae or the popliteal fossa than at the ankle. This suggests an abnormal innervation of the muscle by an accessory deep peroneal nerve, as described by Lambert (1969) and Infante and Kennedy (1970). The course of the accessory motor fibres was analysed in more detail in the subject illustrated in Figs. 9 and 10. Stimulation behind the lateral malleolus elicited a large potential in the lateral part of the extensor digitorum brevis muscle and only a small conducted response in the medial part of the muscle. The antidromic response evoked in the accessory motor fibres was 50 times

TABLE 4

CONDUCTION VELOCITY ALONG MOTOR FIBRES IN DEEP PERONEAL AND POSTERIOR TIBIAL NERVE IN 26 SUBJECTS AGED 15 TO 33 YEARS, AND 20 SUBJECTS 40 TO 65 YEARS

(TEMPERATURE ON SKIN 35 TO $37^{\circ} \mathrm{C}$ )

\begin{tabular}{|c|c|c|c|c|c|}
\hline & \multirow[t]{2}{*}{$\begin{array}{l}\text { Age } \\
(y r)\end{array}$} & \multirow[t]{2}{*}{$n^{1}$} & \multicolumn{3}{|c|}{$\begin{array}{l}\text { Conduction velocity } \\
\quad(\mathrm{m} / \mathrm{sec})\end{array}$} \\
\hline & & & mean & $95 \%$ & $S D$ \\
\hline $\begin{array}{l}\text { N. peron. prof. } \\
\text { poplit. fossa-ankle } \\
\text { (m. extens. dig. brev.) } \\
\text { capitul. fibul.-ankle } \\
\text { (m. extens. dig. brev.) }\end{array}$ & $\begin{array}{l}15-25 \\
40-65 \\
15-33 \\
40-65\end{array}$ & $\begin{array}{l}13 \\
11 \\
21 \\
20\end{array}$ & $\begin{array}{l}51 \cdot 3 \\
50 \cdot 0 \\
51 \cdot 0 \\
49 \cdot 7\end{array}$ & $\begin{array}{l}44 \cdot 0 \\
44 \cdot 0 \\
45 \cdot 0 \\
43 \cdot 0\end{array}$ & $\begin{array}{l}3 \cdot 2 \\
3 \cdot 3 \\
2 \cdot 8 \\
4 \cdot 2\end{array}$ \\
\hline $\begin{array}{l}\text { N. tibial. post. } \\
\text { poplit. fossa-med. } \\
\text { malleol. } \\
\text { (m. abduct. halluc. } \\
\text { brev.) }\end{array}$ & $\begin{array}{l}15-25 \\
40-65\end{array}$ & $\begin{array}{l}26 \\
10\end{array}$ & $\begin{array}{l}51.8 \\
48.6\end{array}$ & $\begin{array}{r}45.0 \\
43.0\end{array}$ & $\begin{array}{r}4.0 \\
2 \cdot 4\end{array}$ \\
\hline
\end{tabular}

${ }^{1}$ Number of nerves. larger when picked up from the common peroneal nerve in the popliteal fossa than when recorded at the capitulum fibulae, where the electrode was situated near the superficial peroneal nerve. This indicates that the accessory motor fibres joined the superficial peroneal nerve proximal to the capitulum fibulae (Fig. 10).

\section{DISCUSSION}

In all subjects except one, sensory potentials were recorded at all sites along the three nerves examined.

TABLE 5

CONDUCTION VELOCITY IN COMMON PERONEAL NERVE ALONG SENSORY AND MOTOR FIBRES ACROSS CAPITULUM FIBULAE IN 15 SUBJECTS AGED 15 TO 25 YEARS, AND 11 SUBJECTS AGED 40 TO 65 YEARS (TEMPERATURE ON SKIN 35 TO $37^{\circ} \mathrm{C}$ )

\begin{tabular}{|c|c|c|c|c|c|}
\hline & \multirow[t]{2}{*}{$\begin{array}{l}\text { Age } \\
(y r)\end{array}$} & \multirow[t]{2}{*}{$n^{1}$} & \multicolumn{3}{|c|}{$\begin{array}{l}\text { Conduction velocity } \\
(\mathrm{m} / \mathrm{sec})\end{array}$} \\
\hline & & & mean & $95 \%$ & $S D$ \\
\hline \multicolumn{6}{|c|}{$\begin{array}{l}\text { Sensory velosity } \\
\text { capitul. fibul.-poplit. }\end{array}$} \\
\hline $\begin{array}{l}\text { fossa } \\
\text { (stim. at sup. ext. }\end{array}$ & $15-25$ & 13 & $55 \cdot 8$ & $47 \cdot 0$ & $4 \cdot 7$ \\
\hline retinas.) & $40-65$ & 11 & $53 \cdot 5$ & $46 \cdot 0$ & $5 \cdot 2$ \\
\hline \multicolumn{6}{|l|}{$\begin{array}{l}\text { Motor velocity } \\
\text { poplit. fossa-capitul. }\end{array}$} \\
\hline fibul. & $15-25$ & 14 & $59 \cdot 6$ & $52 \cdot 0$ & $3 \cdot 7$ \\
\hline $\begin{array}{l}\text { (m. peron. long) } \\
\text { poplit. fossa - capitul. }\end{array}$ & $40-65$ & 11 & $56 \cdot 0$ & $49 \cdot 0$ & $5 \cdot 7$ \\
\hline $\begin{array}{l}\text { poplit. fossa-capitul. } \\
\text { fibul. }\end{array}$ & $15-25$ & 15 & $51 \cdot 8$ & $43 \cdot 0$ & $5 \cdot 0$ \\
\hline (m. extens. dig. brev.) & $40-65$ & 11 & $49 \cdot 8$ & $42 \cdot 5$ & $4 \cdot 3$ \\
\hline
\end{tabular}

${ }^{1}$ Number of nerves. 
TABLE 6

DISTAL MOTOR LATENCY AND AMPLITUDE OF MUSCLE ACTION POTENTIAL EVOKED BY STIMULATION OF COMMON PERONEAL AND POSTERIOR TIBIAL NERVE IN 22 SUBJECTS AGED 15 TO 33 YEARS, AND 20 SUBJECTS AGED 40 TO 65 (TEMPERATURE ON SKIN 35 to $37^{\circ} \mathrm{C}$ )

\begin{tabular}{|c|c|c|c|c|c|c|c|c|c|}
\hline & \multirow{2}{*}{$\begin{array}{l}\text { Age } \\
(y r)\end{array}$} & \multirow[t]{2}{*}{$n^{1}$} & \multicolumn{3}{|c|}{ Latency (msec) } & \multicolumn{3}{|c|}{ Amplitude ( $m V)$} & \multirow{2}{*}{$\begin{array}{c}\text { Distance } \\
(\mathrm{cm})\end{array}$} \\
\hline & & & mean & $95 \%$ & $S D$ & mean & $95 \%$ & $S D$ & \\
\hline \multicolumn{10}{|l|}{ N. peroneus communis } \\
\hline Poplit. fossa $-\mathrm{m}$. peron. long & $15-30$ & 18 & $4 \cdot 6$ & $5 \cdot 1$ & $0 \cdot 38$ & $15 \cdot 0$ & $6 \cdot 0$ & $5 \cdot 2$ & $17 \cdot 5-26 \cdot 0$ \\
\hline (standard distance $21 \mathrm{~cm}$ ) & $40-65$ & 11 & $5 \cdot 0$ & $5 \cdot 6$ & $0 \cdot 37$ & $15 \cdot 5$ & $9 \cdot 0$ & $4 \cdot \overline{8}$ & $18 \cdot 5-24 \cdot 0$ \\
\hline Capitul. fibul. -m. peron. long & $15-33$ & 20 & $2 \cdot 8$ & $3 \cdot 4$ & $0 \cdot 30$ & $16 \cdot 5$ & $7 \cdot 0$ & $4 \cdot 9$ & $7 \cdot 5-12 \cdot 5$ \\
\hline (standard distance $10 \mathrm{~cm}$ ) & $40-65$ & 11 & $3 \cdot 1$ & $3 \cdot 7$ & 0.36 & $18 \cdot 5$ & $8 \cdot 0$ & $6 \cdot 8$ & $8 \cdot 5-12 \cdot 0$ \\
\hline Ankle-m. extens. dig. brev. & $15-33$ & 22 & $4 \cdot 4$ & $5 \cdot 1$ & 0.57 & $12 \cdot 5$ & $3 \cdot 0$ & $5 \cdot 6$ & $6 \cdot 0-11 \cdot 0$ \\
\hline (standard distance $9 \mathrm{~cm}$ ) & $40-65$ & 20 & $4 \cdot 1$ & $5 \cdot 1$ & 0.52 & $11 \cdot 0$ & $3 \cdot 5$ & $4 \cdot 8$ & $7 \cdot 0-11 \cdot 0$ \\
\hline \multicolumn{10}{|l|}{ N. tibialis posterior } \\
\hline Poplit. fossa-m. gastrocnem. & $15-18$ & 13 & $4 \cdot 8$ & $5 \cdot 3$ & $0 \cdot 36$ & $22 \cdot 0$ & $6 \cdot 0$ & $8 \cdot 8$ & $16 \cdot 0-22 \cdot 5$ \\
\hline (standard distance $18 \mathrm{~cm}$ ) & $40-52$ & 7 & $4 \cdot 7$ & $5 \cdot 5$ & 0.42 & $26 \cdot 5$ & $7 \cdot 0$ & $11 \cdot 6$ & $17 \cdot 0-19 \cdot 0$ \\
\hline \multicolumn{10}{|c|}{ Med. malleol. -m. abduct. halluc. } \\
\hline brev. & $15-25$ & 21 & $3 \cdot 9$ & $4 \cdot 8$ & $0 \cdot 50$ & $18 \cdot 5$ & $6 \cdot 0$ & 6.6 & $7 \cdot 5-12 \cdot 5$ \\
\hline (standard distance $10 \mathrm{~cm}$ ) & $40-65$ & 10 & $3 \cdot 9$ & $5 \cdot 1$ & $0 \cdot 37$ & $12 \cdot 5$ & $3 \cdot 5$ & $6 \cdot 1$ & $8 \cdot 0-12 \cdot 5$ \\
\hline
\end{tabular}

${ }^{1}$ Number of nerves.

The maximum sensory conduction velocity along the superficial peroneal, sural, and posterior tibial nerve was the same. In contrast with Thomas, Sears, and Gilliatt (1959) and in agreement with Gassel and Trojaborg (1964), we found the same conduction velocity along motor fibres of the peroneal and posterior tibial nerves. The average velocity along corresponding segments of sensory and motor nerves is therefore a suitable basis for comparison with findings in patients (Table 7).
In the nerves of the leg, as of the arm, the maximum sensory velocity along the distal segments was slower than the proximal velocity, slowing being most pronounced along the terminal branches. A $\bar{\theta}$ in the median and ulnar nerves the maximur velocity in the nerves of the leg was lower at 40 t $\overrightarrow{0}$ 65 years of age than at 15 to 30 years, slowing with age being equally pronounced along distal as alon proximal segments. The lower incidence of large fibres cannot account for the lower velocity

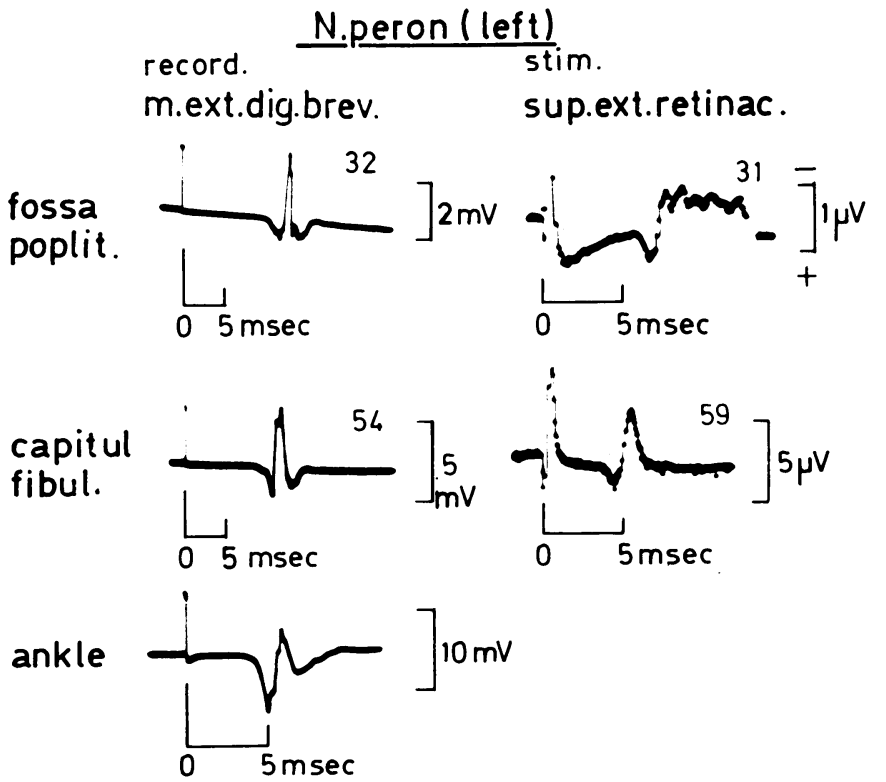

FIG. 8. Slowing in motor and sensory fibres of the peroneal nerve across the capitulum fibulae (temperature on the skin 34 to $35^{\circ} \mathrm{C}$ ). The maximum conduction velocity across the capitulum fibulae was $32 \mathrm{~m} / \mathrm{sec}$ (motor) and $31 \mathrm{~m} / \mathrm{sec}$ (sensory) and distal to it $54 \mathrm{~m} / \mathrm{sec}$ (motor) and $59 \mathrm{~m} / \mathrm{sec}$ (sensory). A fisherman, 50 years old, who had repeated attacks of low back pain in the past 12 years. Three weeks previously he had noticed weakness of dorsal flexion and numbness on the dorsal aspect of the left foot. There was no wasting, the tendon reflexes were normal, and the sensitivity to touch and pin-prick was decreased in the distribution of the peroneal nerve. 
M.extensor dig. brev.

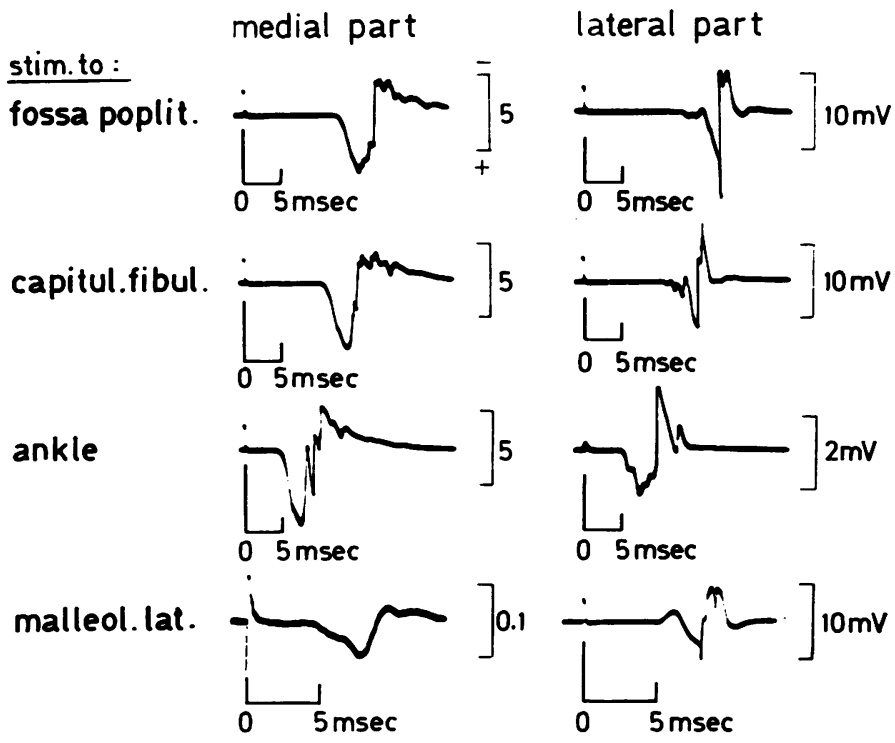

FIG. 9. Innervation of the extensor digitorum brevis muscle by an accessory deep peroneal nerve was indicated by (1) a five times larger amplitude of the action potential in the lateral part of the muscle (right) when stimulating at the popliteal fossa or the capitulum fibulae than when stimulating at the ankle. This difference was absent when recording in the centre of the belly of the muscle (left); (2) stimulating behind the lateral malleolus evoked a large action potential in the lateral part and a small conducted response in the centre of the belly of the muscle. Subject J.J., male, 16 years old, left leg (temperature on the skin 35 to $37^{\circ} \mathrm{C}$ ).

because some large fibres are present (Swallow, 1966; O'Sullivan and Swallow, 1968) and segmental demyelination is uncommon below 65 years of age (Lascelles and Thomas, 1966).

Findings differed in the nerves of the lower and of the upper extremities in the following respects. (1) The amplitude of the sensory potentials in the

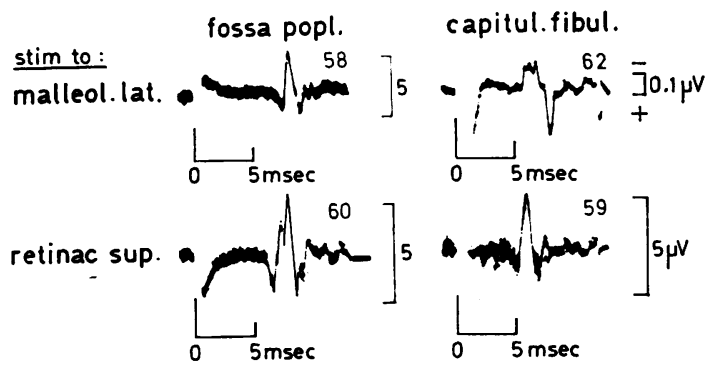

FIG. 10. To show that the accessory branch joins the common peroneal nerve proximal to the capitulum fibulae. The antidromic response evoked in the accessory peroneal nerve by stimulating behind the lateral malleolus was large in the popliteal fossa and small at the capitulum fibulae (upper traces). In the same position (lower traces) the electrodes recorded large potentials from the superficial peroneal nerve both at the capitulum fibulae and in the popliteal fossa. The figures above the traces give the maximum conduction velocity $(\mathrm{m} / \mathrm{sec})$. Subject and temperature as in Fig. 9. leg was smaller than in the arm, 10 times smaller at the ankle than at the wrist. (2) Potentials recorded between toes and ankle were split up into many components; at the wrist they were smooth and triphasic and only in the old subjects split up into a few components. This difference is not due to the 5 to $7 \mathrm{~cm}$ longer distance of conduction in the foot than in the hand, because split-up components in the foot were more pronounced at a distance of $20 \mathrm{~cm}$ than at the elbow at a distance of $40 \mathrm{~cm}$. (3) The maximum conduction velocity along the sensory fibres of the leg was $10 \mathrm{~m} / \mathrm{sec}$ slower than in the arm. The minimum velocity was the same in the leg and in the arm, and corresponded to fibres of 2 to $4 \mu$ in diameter. (4) The maximum sensory velocity in the leg was $5 \mathrm{~m} / \mathrm{sec}$ faster than the motor velocity, whereas there was no consistent difference between sensory and motor fibres in the arm. The conduction velocity along the mixed posterior tibial nerve was similar to the velocity along sensory fibres, and $7 \mathrm{~m} / \mathrm{sec}$ faster than along motor fibres (Mayer, 1963).

The maximum sensory velocity along the proximal segment of the nerves was the same as found by Sato (1967) and 3 to $10 \mathrm{~m} / \mathrm{sec}$ faster than in other studies (Mavor and Atcheson, 1966; Shiozawa and Mavor, 1969; Lovelace et al., 1969, DiBenedetto, 1970), possibly because of a higher temperature. In the distal segment of the posterior tibial nerve Mavor and Atcheson (1966) and Ertekin (1969; 
TABLE 7

AVERAGE MAXIMUM AND MINIMUM CONDUCTION VELOCITY ALONG SENSORY FIBRES AND MAXIMUM VELOCITY ALONG MOTOR FIBRES IN 34 SUBJECTS AGED 15 TO 33 YEARS, AND 37 SUBJECTS AGED 40 TO 65 YEARS (TEMPERATURE ON SKIN 35 TO $37^{\circ} \mathrm{C}$ )

\begin{tabular}{|c|c|c|c|c|c|}
\hline & \multirow{2}{*}{$\begin{array}{l}\text { Age } \\
(y r)\end{array}$} & \multirow[t]{2}{*}{$n^{1}$} & \multicolumn{3}{|c|}{ Conduction velocity $(\mathrm{m} / \mathrm{sec})$} \\
\hline & & & mean & $95 \%$ & $S D$ \\
\hline Maximal distal sensory velocity & $15-30$ & 42 & $46 \cdot 1$ & $39 \cdot 5$ & 3.7 \\
\hline N. peron. superficial and N. tibial post. & $40-65$ & 27 & $42 \cdot 5$ & $36 \cdot 0$ & $5 \cdot 5$ \\
\hline Maximum proximal sensory velocity & 15-33 & 65 & $56 \cdot 5$ & $52 \cdot 0$ & 3.4 \\
\hline N. peron. superficial., N. suralis and N. tibial post. & $40-65$ & 41 & $53 \cdot 1$ & $47 \cdot 5$ & $4 \cdot 6$ \\
\hline Minimum sensory velocity ${ }^{2}$ & $15-30$ & 31 & $19 \cdot 3$ & $10 \cdot 5$ & $5 \cdot 0$ \\
\hline N. peron. superficial., N. suralis and $\mathbf{N}$. tibial, post. & $40-60$ & 16 & $21 \cdot 6$ & $14 \cdot 0$ & $5 \cdot 0$ \\
\hline Motor velocity & 15-30 & 46 & $51 \cdot 4$ & $46 \cdot 0$ & $4 \cdot 2$ \\
\hline N. peron. prof. and N. tibial. post. & $40-65$ & 30 & $49 \cdot 3$ & 43.0 & $4 \cdot 1$ \\
\hline
\end{tabular}

'Number of nerves.

${ }^{2}$ The minimum sensory velosity is the average from findings at the superior extensor retinasulum and the capitulum fibulae (superficial peroneal $c$ nerve); at the lateral malleolus and the sura (sural nerve) and at the medial malleolus (posterior tibial nerve).

found an $8 \mathrm{~m} / \mathrm{sec}$ slower conduction than in our subjects, due either to a lower temperature or to a different point of reference on the potential for the measurement of latency.

When the conduction across the capitulum fibulae is measured, error may arise in the conduction distance because the nerve does not run parallel to the surface. Measurements along the exposed nerve have shown that the error of the conduction was negligible as long as the segment examined was less than $12 \mathrm{~cm}$. The maximum conduction velocity was the same across the capitulum fibulae as distal to it; reduction of $9 \mathrm{~m} / \mathrm{sec}$ or more indicates local impairment.

The faster velocity along nerves to proximal than to distal muscles of the leg, also found by Gassel and Trojaborg (1964), indicates the presence of fibres with larger diameter in the nerves supplying proximal muscles, histologically demonstrated in rabbits (Fernand and Young, 1951).

\section{REFERENCES}

Andersen, V. O., and Buchthal, F. (1970). Low noise a.c. amplifier and compensator to reduce stimulus artefact. Med. biol. Engng., 8, 501-508.

Buchthal, F., and Rosenfalck, A. (1966). Evoked action potentials and conduction velocity in human sensory nerves. Brain Res., 3 (special issue), pp. 122.

Buchthal, F., and Rosenfalck, A. (1971). Sensory potentials in polyneuropathy. Brain (in press).

DiBenedetto, M. (1970). Sensory nerve conduction in lower extremities. Arch. phys. Med., 51, 253-258.

Downie, A. W., and Scott, T. R. (1967). An improved technique for radial nerve conduction studies. J. Neurol. Neurosurg. Psychiat., 30, 332-336.

Ertekin, C. (1969). Saphenous nerve conduction in man. J. Neurol. Neurosurg. Psychiat., 32, 530-540.

Fernand, V. S. V., and Young, J. Z. (1951). The sizes of the nerve fibres of muscle nerves. Proc. roy. Soc. B., 139, 38-58.

Gassel, M. M., and Trojaborg, W. (1964). Clinical and electrophysiological study of the pattern of conduction $\vec{\omega}$ times in the distribution of the sciatic nerve. J. Neurol. Neurosurg. Psychiat., 27, 351-357.

Gilliatt, R. W., Goodman, H. V., and Willison, R. G. (1961). ? The recording of lateral popliteal nerve action potentials $\underset{\perp}{\omega}$ in man. J. Neurol. Neurosurg. Psychiat., 24, 305-318.

Infante, E., and Kennedy, W. R. (1970). Anomalous branch of the peroneal nerve detected by electromyography. Arct Neurol. (Chic.), 22, 162-165.

Jimenez, J., Easton, J. K. M., and Redfort, J. B. (1970 Conduction studies of the anterior and posterior tibial nerves. Arch. phys. Med., 51, 164-169.

Lambert, E. H. (1969). The accessory deep peroneal nerveg a common variation in innervation of extensor digitoruex brevis. Neurology (Minneap.), 19, 1169-1176.

Lascelles, R. G., and Thomas, P. K. (1966). Changes due age in internodal length in the sural nerve in man. Neurol. Neurosurg. Psychiat., 29, 40-44.

Lovelace, R. E., Myers, S. J., and Zablow, L. (1969). Sensory conduction in peroneal, posterior tibial, and sural nerves using averaging techniques. (Abstract.), VIIth $\supseteq$ International Congress of Electroencephography and $\bar{O}$ Clinical Neurophysiology, 1969. Electroenceph. clin. Neurophysiol., 27, 726.

Mavor, H., and Atcheson, J. B. (1966). Posterior tibial nerve conduction. Velocity of sensory and motor fibres. Arch. Neurol. (Chic.), 14, 661-669.

Mayer, R. F. (1963). Nerve conduction studies in man. Neurology (Minneap.), 13, 1021-1030.

O'Sullivan, D. J., and Swallow, M. (1968). The fibre size and content of the radial and sural nerves. J. Neurol. Neurosurg. Psychiat., 31, 464-470.

Sato, K. (1967). Nerve conduction studies in man. Electromyography, 7, 175-176.

Shiozawa, R., and Mavor, H. (1969). In vivo human sural nerve action potentials. J. appl. Physiol., 26, 623-629.

Slomić, A., Rosenfalck, A., and Buchthal, F. (1968). Electrical and mechanical responses of normal and 0 myasthenic muscle. With particular reference to the staircase phenomenon. Brain. Res. 10 (special issue), pp. 78. Swallow, M. (1966). Fibre size and content of the anterior tibial nerve of the foot. J. Neurol. Neurosurg. Psychiat., 29, $\mathrm{N}$
205-213.

Thomas, P. K., Sears, T. A., and Gilliatt, R. W. (1959). The range of conduction velocity in normal motor nerve fibres 0 to the small muscles of the hand and foot. J. Neurol. $\mathbb{\omega}$ Neurosurg. Psychiat., 22, 175-181. 